\title{
Market Intervention in Procurement of Onion: A Case Study of Direct Procurement Vs Price Deficiency Payment Scheme
}

\author{
M. G. Kerutagi ${ }^{1 *}$, Vaishnavi ${ }^{2}$ and Niranjan Nadoni ${ }^{2}$ \\ ${ }^{1}$ Department of Social and Allied Sciences, ${ }^{2}$ Cost of Cultivation and Market Intelligence Cell, \\ University of Horticultural Sciences, Bagalkot, India \\ *Corresponding author
}

\section{A B S T R A C T}

\section{Keywords \\ Market intervention scheme, Direct procurement, Price deficiency payment scheme}

Article Info

Accepted:

12 November 2020 Available Online:

10 December 2020

\begin{abstract}
Karnataka government in the year 2016-17 intervened in market to procure onion at Rs. 624 quintal in major crop growing districts to protect onion farmers from distress sale. This move was aimed at boosting and stabilizing the onion prices, which had been ruling at abnormally low levels. During the year 2016-17 through Procurement Scheme 5,10,397 quintals of onions were procured from 8,714 farmers and government incurred Rs.51.19 crores loss. In case of Price Deficiency Payment Scheme 2,99,954 quintals of onions were sold from 7,064 farmers in Bagalkot and Gadag district during the year 2018-19. And loss percentage was negligible because government provided balance amount to farmers rather than onion procurement. Under the new system, the government has fixed the support price level for onion at Rs.700 per quintal and the Price Deficiency Payment level at Rs.200. Hence, this scheme reduced the burden on government. Farmers also have experienced better profitability by supplying to emerging channels such as marketing through price deficiency payment scheme compared to direct procurement.
\end{abstract}

\section{Introduction}

Market Intervention Scheme (MIS) is to protect the farmers against distress sales of agricultural /Horticultural commodities in the event of a bumper crop during the peak arrival period, when prices tend to fall below cost of production. Under the scheme, in accordance with MIS guidelines, a predetermined quantity at a fixed Market Intervention Price (MIP) is procured by NAFED as the Central Agency and the agencies designated by the State government for a fixed period or till the prices are stabilized above the MIP whichever is earlier. The condition for MIS is that there should be at least a 10 per cent increase in production or a 10 per cent decrease in the ruling market price over the previous normal year.

The scheme is implemented at the request of a State government which is ready to bear 50 percent of the loss (25 percent in the case of North-Eastern States), if any, incurred on implementation. The extent of total loss is to be shared on 50:50 bases between the Central and State Governments and is restricted to 25 percent of the total procurement value, which 
includes cost of the commodity procured plus permitted overhead expenses. The scheme is also known as "Revolving Fund and Floor Price Scheme for Agricultural/Horticultural commodities in Karnataka".

Onion is one of the most significant and commonly used ingredients in Indian recipe. Despite substantial production and trade opportunities, India suffers from very high volatility in onion price (Sudhir, 2004). Years of high onion prices are often followed by years of low onion prices that do not allow onion growers to recover their production costs (Deshmukh, 2015). The changes in prices have a huge impact on the food security, farmer and consumer welfare. There is enough evidence to show that prices of agricultural commodities are more volatile than those of the non-farm commodities (Chengappa et al., 2012).

Volatility in prices of onion has a significant effect on both producers and consumers. There is no mechanism of administered price (such as minimum support price) for onion. However, the MIS that is implemented on request of state government for procurement of agricultural and horticultural commodities. In recent years, we find that MIS has not been implemented in many states and has failed where the scheme was implemented (Rajkumar, 2005; Anon, 2012).

In case of external trade, NAFED (National Agricultural Cooperative Marketing Federation of India Ltd.) is responsible for fixing the minimum export price (MEP) of onion in collaboration with DGFT (Director General of Foreign Trade), which is done on fort-night to a monthly basis.

Factors such as market trends, world prices, domestic prices and margins are considered for arriving at the MEP of onion (Chengappa et al, 2012). One of the major policy instruments to regulate onion export is Minimum Export Price (MEP) which is also a tool to curb inflation, thus contributing to domestic price stabilization.

The key benefit from the price deficiency payment is that it will reduce the need for the government to actually procure food crops, transport and store them and then dispose them through Public distribution system. After the implementation of Price Deficiency Payment Scheme in Karnataka its performance study has not been conducted. It is not clearly evidenced which system is efficient. Hence, the present study is an attempt to know the comparative efficiency and to know the difficulties of operation of the two schemes. The specific objectives were as follows.

The main objectives of this study include to examine the operation of direct procurement and PDPS undertaken by Karnataka government during 2013-14 to 2018-19. To estimate cost, returns and profit/loss of onion procurement during 2016-17 and cost incurred towards onion PDPS during 2018-19 in pilot districts of Karnataka. To analyze the opinion of farmers, traders and government officials of marketing and horticulture department regarding operation of the scheme

\section{Materials and Methods}

For the present study two districts were selected to interview beneficiary and nonbeneficiary farmers. From each district 2 villages were selected viz. Bevinamatti and Kesanur villages from Bagalkot district and Balaganur and Mallapura villages from Gadag district were selected randomly to conduct opinion survey of onion through direct procurement (2016-17) and PDPS scheme (2018-19). The details of sample districts villages and respondents are given in Table 1. Thus, total sample size was 78 . 


\section{Garrett's ranking}

In order to assess the opinion of farmers, traders, APMC Officials, Horticulture Department Officials and MARKED Officials about PDPS and Direct procurement of onion, the Garrett's ranking technique was used to prioritize the opinion. The order of the merits given by the respondents was changed into ranks by using the following formula.

Percent position $=\frac{100(\mathrm{Rij}-0.5)}{\mathrm{Nj}}$

Where,

$R_{i j}=$ rank given for $i^{\text {th }}$ factor by $j^{\text {th }}$ individual $\mathrm{N}_{\mathrm{j}}=$ number of factors ranked by $\mathrm{j}^{\text {th }}$ individual

The Percent position of each rank was converted into scores by referring the table given by Garrett (Garrett and Woodworth, 1969). For each factor the scores of individual respondents were added together and divided by the total number of respondents for whom scores were added. These mean scores for all the factors were arranged in descending order and the constraints were ranked.

\section{Results and Discussion}

The market intervention schemes are aimed either at directly influencing the prices received by the farmers and those paid by consumers, or influencing the demand. The results presented in the Table 2 revealed that the procurement for onion was implemented only twice viz. 2016-17 and 2018-19 in Karnataka. Karnataka government in the year 2016-17 intervened in market to procure onion at Rs. 624 quintal in major crop growing districts to protect onion growing farmers from distress sale. In the year 201819 PDPS was given if onion price was below Rs.700 per quintal and the Price Deficiency Payment level was fixed at Rs. 200.This move was aimed at boosting and stabilizing the onion prices, which had been ruling at abnormally low levels. Around 8,38,903.37 quintals of onions were procured from 15,025 farmers through the Karnataka State Cooperative Marketing Federation (MARKFED).

The details of cost, return and profit/loss of onion procurement during the year 2016-17 in the study area were presented in Table 3 . In direct procurement scheme 2016-17 government incurred a loss of Rs. 51.19 crores, while in case of PDPS scheme loss percentage was negligible because government provided balance amount to farmers rather than onion procurement. Hence, this scheme reduced the burden on government.

As per the Karnataka Agriculture Price Commission recommendation government initiated "Price Deficiency Payment Scheme" for onion in the year 2018-19 to protect farmers from price crash. Government initiated this scheme in Bagalkot, Belagavi, Gadag and Dharwad. The Price Deficiency Payment system was implemented with 16 conditions that include getting verification regarding crop details from a committee officers at the entrance of the APMC, selling only to registered traders, verification of the quantum of produce by officials of weights and measurements, keeping track of onionloaded vehicles that go out of the APMC yards, and noting down their destinations. In the year 2018-19 PDPS was given if onion price was below Rs. 700 per quintal and the Price Deficiency Payment level at Rs. 200. Around 2,99,954.45 quintals of onions were sold from 7064 farmers through PDPS scheme in Bagalkot and Gadag district. A similar kind of observation was also made by Deepa (2005) benefits accrued to the farmers by selling their produce at procurement centres was found to be higher than that of the market price for major crops of Karnataka (Table 4). 


\section{Opinion of direct procurement and PDPS of Onion in the study area}

Opinion survey conducted to document the opinion of beneficiary and non-beneficiary farmers regarding direct procurement scheme results were presented in Table 5. According to beneficiary farmers of onion direct procurement scheme 2016-17, they opined that delayed payment to sell their produce followed by difficulty in following the procedure, price fixed by government for onion (Rs. 624/ quintal) was less than the production cost of onion and lack of storage facility was the important opinion of farmers towards onion direct procurement scheme. High marketing cost, limitation of procurement quantity of individual farmers, distance of procurement centre and difficulty in meeting FAQ standards were the least important opinion of farmers. According to non-beneficiary farmers of onion direct procurement scheme they felt difficult in following the procedure to sell the produce and due to delayed payment the beneficiary farmers faced financial problems, price fixed in this scheme was lesser than production cost and quantity sold under direct procurement scheme per farmer was limited. Hence, most of the non-beneficiary farmers of onion direct procurement scheme informed that due to its complexity they expressed PDPS scheme is better than onion direct procurement scheme.

Opinion survey conducted to document the opinion of beneficiary and non-beneficiary farmers regarding PDPS Scheme results were presented in Table 6 . According to beneficiary farmers of onion PDPS scheme opined that PDPS price is better than onion procurement price followed by mode of payment method, according to farmers PDPS price is better than the open market, by paying balance amount directly to famers account government reduced the financial risk of the farmers and it also reduced the illegal activities of the intermediaries, so that it helped the farmers from distress sale. Due to PDPS scheme condition farmers sold their produce in APMC to licensed traders so that there was less intervention of market intermediaries. Selling produce in APMC is always helpful to farmers; not only reduces the intermediary activities but also gives assurance about weightage and better price for their produce. During the study it is observed that most of the farmers may not gain profit in onion marketing and at the same time do not incur loss also because of PDPS. According to non-beneficiary farmers of onion PDPS scheme opined that price fixed in PDPS for onion was less than total cost, due to the less price majority of the farmers sold their produce in local market only due to the fear of higher transportation cost, followed by short duration of the scheme majority of the farmers were unaware of the PDPS benefits, non-beneficiary farmers felt lengthy and complex procedure to sell that to limited quantity of produce these were the important opinion of non-beneficiary farmers.

The constraints faced by beneficiary farmers for availing benefits of onion PDPS scheme during the year 2018-19 were presented in Table 7. According to PDPS beneficiary farmers delayed payment and difficulty in following procedure to sell their produce were the major constraints faced by farmers for availing benefits of PDPS. Due to short duration of the scheme most of the farmers from the study area were unaware of the scheme, as per the farmers' opinion the price fixed per quintal of onion even though it was better but it was less than the total cost. Majority of the small and large farmers felt difficult due to quantity limitation of the scheme. High marketing cost, intervention of traders by quoting less price for produce, distance of market place, lack of storage facility and difficulty in meeting in FAQ standards constraints were least expressed by beneficiary farmers. 
Table.1 Selection of study area and sample size

\begin{tabular}{|c|c|c|}
\hline District & Particulars & Sample size \\
\hline \multirow[t]{7}{*}{ Bagalkot } & Beneficiary farmers & 15 \\
\hline & Non-beneficiary farmers & 15 \\
\hline & Traders & 5 \\
\hline & APMC Officials & 1 \\
\hline & Horticulture Officials & 2 \\
\hline & MARKFED & 1 \\
\hline & Sub total & 39 \\
\hline \multirow[t]{7}{*}{ Gadag } & Beneficiary farmers & 15 \\
\hline & Non-beneficiary farmers & 15 \\
\hline & Traders & 5 \\
\hline & APMC Officials & 1 \\
\hline & Horticulture Officials & 2 \\
\hline & MARKFED & 1 \\
\hline & \multirow{2}{*}{ Total } & 39 \\
\hline & & 78 \\
\hline
\end{tabular}

Table.2 Year wise market intervention scheme undertaken by Government of Karnataka for major crops

\begin{tabular}{|c|c|c|c|}
\hline Sl. No. & Year & Crops & $\begin{array}{c}\text { Market Intervention Price } \\
\text { (Rs/Qtl) }\end{array}$ \\
\hline $\mathbf{1}$ & $2013-14$ & White jowar & $2000 /-$ \\
& & Maize & $1310 /-$ \\
\hline $\mathbf{2}$ & $2014-15$ to $2015-16$ & Bengal gram & $3100 /-$ \\
\hline $\mathbf{3}$ & $2016-17$ & Not procured & -- \\
\hline & & Onion & $624 /-$ \\
\hline $\mathbf{4}$ & & Tur & $6000 /-$ \\
\hline $\mathbf{5}$ & $2017-18$ & Green gram & $5225 /-$ \\
\hline & & Tur & $6000 /-$ \\
\hline
\end{tabular}

Table.3 Cost, return and profit/ loss of onion procurement during 2016-17 in the study area

\begin{tabular}{|c|c|c|c|c|c|}
\hline District & $\begin{array}{c}\text { Total farmers } \\
\text { (No.) }\end{array}$ & $\begin{array}{c}\text { Total } \\
\text { purchase } \\
\text { (Qtls) }\end{array}$ & $\begin{array}{c}\text { Value @ Rs. 624/ } \\
\text { qtls }\end{array}$ & $\begin{array}{c}\text { Total fund } \\
\text { received } \\
\text { (Revolving fund) }\end{array}$ & $\begin{array}{c}\text { Total onion } \\
\text { sold } \\
\text { Amt (Rs.) }\end{array}$ \\
\hline Bagalkot & 2,093 & $1,21,226.00$ & $7,56,45,024.00$ & $4,44,75,000.00$ & $82,07,020.00$ \\
\hline Gadag & 6,621 & $3,89,171.22$ & $25,06,26,265.68$ & $21,20,76,849.00$ & $4,93,27,426.00$ \\
\hline Total & $\mathbf{8 , 7 1 4}$ & $\mathbf{5 , 1 0 , 3 9 7 . 2 2}$ & $\mathbf{3 2 , 6 2 , 7 1 , 2 8 9 . 6 8}$ & $\mathbf{2 5 , 6 5 , 5 1 , 8 4 9 . 0 0}$ & $\mathbf{5 , 7 5 , 3 4 , 4 4 6 . 0 0}$ \\
\hline
\end{tabular}


Table.4 Implications of onion PDPS scheme in the study area

\begin{tabular}{|l|c|c|c|c|}
\hline District & $\begin{array}{c}\text { Total } \\
\text { farmers } \\
\text { (No.) }\end{array}$ & $\begin{array}{c}\text { Quantity sold below } \\
\text { (qtls) Rs.700 /qtl }\end{array}$ & $\begin{array}{c}\text { Difference amount } \\
\text { (Rs.) }\end{array}$ & $\begin{array}{c}\text { Quantity sold (qtls) } \\
\text { above Rs.700 }\end{array}$ \\
\hline Bagalkot & 2,423 & 88,265 & $1,66,48,768.00$ & $3,670.00$ \\
\hline Gadag & 4,641 & $2,11,669$ & $4,19,98,436.11$ & 556.00 \\
\hline Total & $\mathbf{7 , 0 6 4}$ & $\mathbf{2 , 9 9 , 9 3 4}$ & $\mathbf{5 , 8 6 , 4 7 , 2 0 4 . 1 1}$ & $\mathbf{4 , 2 2 6 . 0 0}$ \\
\hline
\end{tabular}

Table.5 Beneficiary and Non-beneficiary farmers' opinion about onion direct procurement scheme during the year 2018-19

\begin{tabular}{|c|l|c|c|}
\hline $\begin{array}{l}\text { Sl. } \\
\text { No. }\end{array}$ & \multicolumn{1}{|c|}{ Particulars } & $\begin{array}{c}\text { Mean } \\
\text { score }\end{array}$ & Ranking \\
\hline Beneficiary farmers & & \\
\hline $\mathbf{1}$ & Delayed payment & 69.13 & I \\
\hline $\mathbf{2}$ & Difficulty in following the Procedure & 68.87 & II \\
\hline $\mathbf{3}$ & Procurement price was less than the cost of production of onion & 67.00 & III \\
\hline $\mathbf{4}$ & Lack of storage facilities & 49.97 & IV \\
\hline $\mathbf{5}$ & High marketing cost & 45.47 & V \\
\hline $\mathbf{6}$ & Purchased quantity limited to individual farmer & 38.23 & VI \\
\hline $\mathbf{7}$ & Procurement centre away from production places & 29.20 & VII \\
\hline $\mathbf{8}$ & Difficulty in meeting FAQ standards & 28.13 & VIII \\
\hline $\mathbf{N o n}-$ beneficiary farmers & & 67.03 & I \\
\hline $\mathbf{9}$ & Difficulty in following the Procedure & 65.53 & II \\
\hline $\mathbf{1 0}$ & Delayed payment & 60.23 & III \\
\hline $\mathbf{1 1}$ & Procurement price was less than the cost of production of onion & 49.53 & IV \\
\hline $\mathbf{1 2}$ & Purchased quantity limited to individual farmer & 48.23 & V \\
\hline $\mathbf{1 3}$ & High marketing cost & 33.67 & VI \\
\hline $\mathbf{1 4}$ & Procurement centre is away from production place & 32.27 & VII \\
\hline $\mathbf{1 5}$ & Lack of storage facilities in the APMC & 29.00 & VIII \\
\hline $\mathbf{1 6}$ & Lack of awareness regarding FAQ standards & & \\
\hline & & & \\
\hline
\end{tabular}

Table.6 Beneficiary and Non-beneficiary farmers' opinion about onion PDPS scheme during the year 2018-19

\begin{tabular}{|c|l|c|c|}
\hline \multicolumn{1}{|c|}{ Particulars } & Mean score & Ranking \\
\hline \multicolumn{1}{|l|}{ Noneficiary Farmers } & & \\
\hline $\mathbf{1}$ & PDPS price is better than onion procurement price & 68.00 & I \\
\hline $\mathbf{2}$ & Better mode of payment & 62.27 & II \\
\hline $\mathbf{3}$ & Better price than open market price & 61.27 & III \\
\hline $\mathbf{4}$ & Reduced financial risk of the farmers & 47.03 & IV \\
\hline $\mathbf{5}$ & Helped to overcome from distress sale & 32.10 & V \\
\hline $\mathbf{6}$ & Less intervention of market intermediaries & 30.57 & VI \\
\hline
\end{tabular}




\begin{tabular}{|c|l|c|c|}
\hline Non-beneficiary farmers & 69.50 & I \\
\hline $\mathbf{7}$ & PDPS price is lower than the total cost & 68.50 & II \\
\hline $\mathbf{8}$ & Short duration of the scheme & 66.43 & III \\
\hline $\mathbf{9}$ & Lack of awareness of the scheme & 65.73 & IV \\
\hline $\mathbf{1 0}$ & Difficulty in following the procedure & 52.83 & V \\
\hline $\mathbf{1 1}$ & Quantity limitation (per farmer) & 39.40 & VI \\
\hline $\mathbf{1 2}$ & High marketing cost & 37.07 & VII \\
\hline $\mathbf{1 3}$ & Difficulty in transportation & 32.67 & VIII \\
\hline $\mathbf{1 4}$ & Difficulty in meeting FAQ standards & 32.30 & IX \\
\hline $\mathbf{1 5}$ & Lack of storage facility & 30.57 & X \\
\hline $\mathbf{1 6}$ & Market place away from the production places & & \\
\hline
\end{tabular}

Table. 7 Constraints faced by the beneficiary farmers for availing benefits of onion PDPS scheme during the year 2018-19

\begin{tabular}{|c|l|c|c|}
\hline SI. No. & \multicolumn{1}{|c|}{ Particulars } & Mean score & Ranking \\
\hline $\mathbf{1}$ & Delayed payment & 76.30 & I \\
\hline $\mathbf{2}$ & Difficulty in following the Procedure & 65.33 & II \\
\hline $\mathbf{3}$ & Short duration of the scheme & 61.00 & III \\
\hline $\mathbf{4}$ & PDPS price is lower than the total cost & 58.47 & IV \\
\hline $\mathbf{5}$ & Purchased quantity limited to individual farmer & 45.50 & V \\
\hline $\mathbf{6}$ & High marketing cost & 45.23 & VI \\
\hline $\mathbf{7}$ & Intervention of traders by quoting less price & 43.97 & VII \\
\hline $\mathbf{8}$ & Market area is away from production places & 35.50 & VIII \\
\hline $\mathbf{9}$ & Lack of storage facility & 34.57 & IX \\
\hline $\mathbf{1 0}$ & Difficulty in meeting FAQ standards & 28.73 & X \\
\hline
\end{tabular}

Table.8 Opinion about onion PDPS Scheme during the year 2018-19

\begin{tabular}{|c|c|c|c|}
\hline Sl. No. & Particulars & Mean score & Ranking \\
\hline I & Traders & & \\
\hline 1 & Faced difficulty in deciding the price of the produce & 72.80 & I \\
\hline 2 & $\begin{array}{l}\text { Reduced the commission agent and non license trader } \\
\text { involvement }\end{array}$ & 55.80 & II \\
\hline 3 & Majority of the farmers failed to manage the quality parameters & 51.00 & III \\
\hline 4 & PDPS reduced the burden on government regarding to storage & 47.40 & IV \\
\hline 5 & Better mode of payment & 37.90 & $\mathrm{~V}$ \\
\hline 6 & Reduced the price risk of the farmers & 33.10 & VI \\
\hline II & APMC Secretary & & \\
\hline 1 & PDPS reduced the burden on government regarding to storage & 71.50 & I \\
\hline 2 & Better mode of payment & 61.00 & II \\
\hline 3 & Some traders misused the scheme by quoting less price & 56.00 & III \\
\hline 4 & Reduced the price risk of the farmers & 46.00 & IV \\
\hline 5 & $\begin{array}{l}\text { Reduced the commission agent and non license trader } \\
\text { involvement }\end{array}$ & 45.50 & $\mathrm{~V}$ \\
\hline
\end{tabular}




\begin{tabular}{|c|c|c|c|}
\hline 6 & Farmers faced the difficulty in following the procedure & 35.50 & VI \\
\hline 7 & $\begin{array}{l}\text { Some traders resale the produce as a farmer in market to get } \\
\text { PDPS benefit }\end{array}$ & 31.50 & VII \\
\hline III & Horticulture department official's & & \\
\hline 1 & Reduced the price risk of the farmers & 65.75 & I \\
\hline 2 & PDPS reduced the burden on government regarding to storage & 62.50 & II \\
\hline 3 & $\begin{array}{l}\text { Reduced the commission agent and non license trader } \\
\text { involvement }\end{array}$ & 55.25 & III \\
\hline 4 & Farmers faced the difficulty in following the procedure & 53.75 & IV \\
\hline 5 & Some traders misused the scheme by quoting less price & 45.75 & $\mathrm{~V}$ \\
\hline 6 & Better mode of payment & 39.75 & VI \\
\hline 7 & $\begin{array}{l}\text { Some traders resale the produce as a farmer in market to get } \\
\text { PDPS benefit }\end{array}$ & 24.25 & VII \\
\hline
\end{tabular}

Table.9 Opinion about onion direct procurement scheme during the year 2018-19

\begin{tabular}{|c|c|c|c|}
\hline Sl. No. & Particulars & Mean score & Ranking \\
\hline I & Traders & & \\
\hline 1 & Quoted higher price due to Government procurement price & 61.90 & I \\
\hline 2 & $\begin{array}{l}\text { Difficulty in quoting the price as Government procured } \\
\text { onion at Rs. } 624\end{array}$ & 60.40 & II \\
\hline 3 & Unable to purchase expected quantity & 48.50 & III \\
\hline 4 & Unscientific method of purchasing the produce & 47.70 & IV \\
\hline 5 & Storage problem in the APMC & 28.50 & V \\
\hline II & Branch Manager (MARKFED) & & \\
\hline 1 & $\begin{array}{l}\text { Increased the burden on government regarding to onion } \\
\text { storage }\end{array}$ & 67.50 & I \\
\hline 2 & All quality of onion got same price & 62.50 & II \\
\hline 3 & Faced difficulty in onion storage due to its perishable nature & 49.50 & III \\
\hline 4 & Farmers faced the difficulty in following the procedure & 44.50 & IV \\
\hline 5 & Procurement centre was away from production area & 24.00 & V \\
\hline
\end{tabular}

These results were in accordance with the study conducted by Rajkumar et al., (2005) who studied the main problems being faced by the farmers in availing MIS benefits have been identified to include procedural problems (89\%), FAQ requirements $(82 \%)$ and delayed payment $(71 \%)$ stipulation for the crop. It has also been revealed that further are the procurement centres, more is the likelihood of the farmers to go in for open market sales. The study has suggested covering a larger number of farmers under MIS by simplifying the procedures, making timely payments and increasing the number of procurement centres.
Table 8 revealed that the Traders, APMC secretary, Horticultural department officials opinion about onion PDPS scheme during the year 2018-19. According to Bagalkot and Gadag district Traders opined about onion PDPS scheme 2018-19 that they faced difficulty in deciding the price of the produce as government fixed price of onion. Due to PDPS scheme the activity of commission agent and non license trader was reduced as per the scheme to avail PDPS benefits. Farmers sold their produce in APMC and licensed trader so that involvement of non license holder and commission agent was remarkably reduced. Due to poor quality of 
produce traders were in dilemma to purchase the produce and due to PDPS scheme burden on government was reduced regarding to storage of onion. They expressed better mode of payment as government paying balance amount directly to farmers account and it also helps to reduce the price risk of the farmers as government assuring price support by fixing onion price based on cost of production (Cost $\mathrm{A} 1+\mathrm{FL})$.

According to APMC Secretary opinion about onion PDPS scheme 2018-19, they expressed that because of PDPS the burden on government reduced regarding onion storage in comparison with onion direct procurement scheme and better mode of payment were expressed as important opinion regarding PDPS. As per the scheme government has to pay balance amount to the farmers but some of the traders quoted lower prices even though onion quality was good. However, because of this scheme price risk of the farmers and involvement intermediaries were reduced significantly. Similarly, Horticulture Department Officials opined about onion PDPS scheme 2018-19 they expressed that, it reduced the price risk of the farmers as open market price was very less, reduced the burden on government with regard to storage and reduced the involvement of intermediaries were the important opinion received. They also expressed difficulty in following the procedure for marginal and small farmers; due to balance payment method some of the traders were quoted less price and better mode of payment were the least expressed opinion by horticulture officials.

Table 9 reveals that the Traders, Branch manager of MARKFED opinion about onion direct procurement scheme during the year 2018-19. According to traders they quoted higher price for poor quality produce for the fear less availability of produce for purchase and they faced difficulty in quoting the price due to government procurement price. Majority of the traders mentioned that this was unscientific method for procurement because for all the quality of onion the price under scheme was similar so that majority of the farmers sold onion under direct procurement scheme.

According to branch manager opinion, due to this scheme burden on government was increased due to onion storage problem as it is perishable in nature, difficult to store it. It should be purchased on quality basis and farmers faced difficulty in selling produce under this scheme due to long distance from procurement centre farmers were paid higher transportation cost. They expressed for all quantity of onion government fixed same price and compared to onion direct procurement scheme onion PDPS is better because of its price fixing and balance amount payment method

In conclusion, india is one of the largest producers of onion with Karnataka being the largest producing State. Farmers also have experienced better profitability by supplying to emerging channels such as market through price deficiency payment scheme compared to direct procurement. High fluctuations in prices are observed even during the implementation of the Market Intervention Scheme in Karnataka. Thus, there is need for greater public intervention to address price volatility in order to ensure cultivators a stable and adequate price. Further, public policy needs to address improved storage, processing facilities and generation of valueadded products. The researcher is also of the opinion that below mentioned problems adversely impact the farmers' profitability due to prevailing distribution practices viz., i) Delayed payment ii) difficulty in following the procedure and iii) short duration of the scheme. Payment should make in the earliest 
and within the stipulated period so that farmers can overcome from financial needs. Price should fix based on total cost rather than Cost $\mathrm{A}_{1}+\mathrm{F}_{1}$ and quantity limitation should be increased so that it will be helpful to all category farmers.

\section{References}

Anonymous., 2012, Annual Report. Department of Agriculture, Cooperation \& Farmers Welfare, Ministry of Agriculture \& Farmers Welfare, Government of India, New Delhi.

Chengappa, P.G., Manjunatha, A.V., Dimble, V. and Shah, K., 2012, Competitive Assessment of Onion Markets in India. Agricultural Development and Rural Transformation Centre, Institute for Social and Economic Change, Bengaluru.

Deepa, S. A., 2005, Performance and Impact of Market Intervention Scheme for Agricultural commodities in Karnataka. MBA (Agribusiness) Thesis, University of Agricultural Sciences, Dharwad.

Deshmukh, A. M., 2015, A Study of Price Instability of Food Crop Onion and the Possibility of Planning in Production of Onion. PhD Thesis, Gokhale Institute of Politics And Economics, Pune.

Rajkumar, P. K., 2005, Market Interventions Scheme in Karnataka: an analysis of its usefulness to the farmers. MBA (Agribusiness) Thesis, University of Agricultural Sciences, Dharwad.

Sharma, P., Gummagolmath, K. C. and Sharma, R. C., 2011, Prices of Onion: An Analysis.. Economic and Political Weekly, Vol. 48(2); 22-25.

Sudhir, B., 2004, Onion Prices and State Intervention. Economic and Political Weekly, Vol. 39(33); 3684-3686.

\section{How to cite this article:}

Kerutagi, M. G., Vaishnavi and Niranjan Nadoni. 2020. Market Intervention in Procurement of Onion: A Case Study of Direct Procurement Vs Price Deficiency Payment Scheme. Int.J.Curr.Microbiol.App.Sci. 9(12): 1482-1491. doi: https://doi.org/10.20546/ijcmas.2020.912.176 